\title{
Constraints Faced by Orange Growers about Production and Marketing Orange
}

\author{
Anita Deshmukh ${ }^{1}$, Sonam Agrawal ${ }^{2 *}$ and Venkteshwar Jallaraph ${ }^{1}$ \\ ${ }^{1}$ ICAR-ATARI, Zone-IX, Jabalpur, India \\ ${ }^{2}$ College of Agriculture, Powarkheda, J.N.K.V.V. (M.P.), India \\ *Corresponding author: sonam.agri@gmail.com (ORCID ID: 0000-0002-4005-6952)
}

Paper No. 877

Received: $12-01-2021$

Revised: 28-02-2021

Accepted: 03-03-2021

\begin{abstract}
The oranges created in Amravati district possessed the biggest share of oranges within the Vidarbha orange market. The orange crop plays a vital role within the economy of the region. Among the fruit crops, orange crop covers about 45,226 ha area in Vidarbha. There is still a good potential toward bringing a lot of area below orange in Vidarbha region. The present paper analyses the information behaviour of orange growers concerning the production of the oranges. The various types of constraints confronted by the orange grower related to production of orange are rootstock availability, labour availability, manures and fertilizers, irrigation, plant protection, capital, availability of loan from co-operative society, technical information, use of growth regulator, supporting and constraints confronted by the orange grower related to marketing of orange are Grading, Transportation, Sale of produce, Packaging, Storage. The study was conducted in the purposively selected Amravati district of the Vidarbha region of Maharashtra state. Five Panchayat Samities from Amravati district were hand-picked purposively covering ten villages from every Panchayat Samiti. Thus, a total of 50 villages and five orange growers from each selected village was selected 250 orange growers constituted the sample size for the present investigation. The main objective of the present paper is to analyze the constraints faced by orange growers in the Amravati District of Maharashtra. Study findings indicated that the orange growers were non-availability of rootstock, high cost of rootstock and fertilizers, uncertainty of electricity supply and difficulties in getting loan were major constraints faced by the farmers which are related to the production. Lack of transport facilities, non-establishment of processing units, and high cost of packing material and non-availability of storage facilities in nearby markets were the major constraints about marketing on orange.

\section{Highlights}

( Study findings indicated that the orange growers were non-availability of rootstock, high cost of rootstock and fertilizers, uncertainty of electricity supply and difficulties in getting loan were major constraints faced by the farmers which are related to the production.

( Lack of transport facilities, non-establishment of processing units, and high cost of packing material and non-availability of storage facilities in nearby markets were the major constraints about marketing on orange.
\end{abstract}

Keywords: Constraints, orange growers, production, marketing

Constraints are defined as the situation or circumstances which restrict or limit the activity or performance of particular production and marketing of orange. In other words, it is recognized as items of difficulty faced by small and marginal orange growers. Constraints play an important role in the production and marketing of orange. As India is predominately an agricultural country having more than three fourth of its production depends

How to cite this article: Deshmukh, A., Agrawal, S. and Jallaraph, V. 2021. Constraints Faced by Orange Growers about Production and Marketing Orange. IJAEB, 14(1): 11-16.

Source of Support: None; Conflict of Interest: None (a) 8 
on agriculture and nearly $50 \%$ of national income is derived from the same. But, Indian agriculture is brought with risk and uncertainly as more than two-thirds of the cultivable land is dependent on the monsoon. The farmers are often not sure about the outcome of agriculture due to weather and market-induced risks.

Moreover, the small size of landholding and information about agriculture, therefore, crop diversification may be adopted strategy for profit maximization supplementary relationships for a competitive product. It may also act as a powerful tool in minimization of risk in the farming business. Under the situation of weather and market-induced risk and capital constraints, diversification may help in stabilizing farm income at a higher level. These considerations make a strong case for crop diversification in Indian conditions (Anonymous 2002). Nagpur mandarin is grown in the Vidarbha region of Maharashtra over 1, 46,040 ha area with the production of 5,97,758 million tons. The cultivation of orange in Maharashtra is mostly confined to the Vidarbha region. The orange crop plays a vital role within the economy of the region (Anonymous 2009 \& Kolhe 2000). Among the fruit crops, orange crop covers about 45,226 ha area in Vidarbha. The Amravati \& Nagpur districts contribute concerning $80 \%$ of the overall area below orange orchards Maharashtra State sharing $48.55 \%$ and $31.45 \%$ respectively. Just in the case of production of Oranges in Vidarbha, larger production is in Amravati districts i.e. 37.36\% whereas that in Nagpur district is $23.87 \%$., thus, it is, seen that the oranges created in Amravati district possessed the biggest share of oranges within the Vidarbha orange market. The biggest orange cultivation and production is in Warud, Morshi, Chandu Bazar, Achalpur and Anjangaon talukas of Amravati district. Orange from these centers has major contribution to Nagpur orange market (Ramshetwad 2001).

The efforts to increase orange production have been made by central and state governments by starting horticulture development programmes. The subsidy on the purchase of fertilizers and plant protection chemicals has also been made available to the orchards. Despite this, the production of orange per hectare is attributed to the non-suitability of technology, lack of knowledge, and characteristics of orange growers, price policy and situational factors. The main objective of the present study is to analyze the constraints faced by orange growers in the Amravati district of Maharashtra (Sadaphal 2000).

\section{METHODOLOGY}

The study was conducted in purposively selected Amravati district of the Vidarbha region of Maharashtra state was hand-picked purposively attributable to the larger area below mandarin orange cultivation within the state. The exploratory research design was used. Based on the maximum area below mandarin orange cultivation five Panchayat Samities from Amravati district were hand-picked purposively (Raju and Jayarama 2003) considering the said knowledge Chandur Bazar, Warud, Morshi, Achalpur and Anjangaon from Amravati district were handpicked and ten villages from every taluka were purposively selected. Taluka Agriculture Officer of the chosen talukas was contacted and a list of 10 villages having a lot of area below orange Mandarin fruits was selected (Mishra et al. 2015). Thus, a total of 50 villages were selected from five talukas and five orange growers having more area under orange cultivation was selected thus, total of 250 orange growers constituted the sample size for the present study. Construction of interview schedule for an assortment of knowledge was the foremost necessary aspect, and therefore the basis for the social analysis. Data were collected by pre-tested structured interview schedule through face-to-face interviews (Mishra and Homa 2019).

\section{RESULTS AND DISCUSSION}

\section{Production constraints faced by orange growers}

Production constraints have been operationalized as several limiting factors that determine the quantity and nature of output that a producer can accomplish within a given time. The ten different components on production constraints have been enlisted and farmer's responses based on severity are taken (Sunil 2004). The orange growers were asked to state the difficulties they faced in the production and marketing of orange. Though the responses of the orange growers on constraints about the use 
of recommended orange production technologies and constraints connected with the marketing of oranges were identified and presented in Table 1. The constraints depicted in Table 1 revealed that majority of the orange growers were found to faced the problem of the high cost of rootstocks $(94.40 \%)$ and non-availability of disease-free rootstock (94.00) followed by 88.00 per cent of the orange growers having problem of non-availability of rootstock in large quantity and exactly half (50\%) of the orange growers reported the problem of non-availability of quality rootstocks of recommended variety in time at reasonable rates. Concerning labour, high labour wages were the prime constraints reported by the majority $(76.00 \%)$ of the orange growers followed by non-availability of labour in time $(46.40 \%)$ and lack of skilled labour (36.00\%) (Mahajan 2000).

In the case of manures and fertilizers, major constraints were of the high cost of fertilizers $(89.60 \%)$ and lack of knowledge about fertilizer use $(59.20 \%)$. Other constraints faced by the orange growers were non-availability of fertilizers at the required quantity $(44.80 \%)$, non-availability of fertilizers in time $(43.60 \%)$ and non-availability of fertilizers mixture $(32.00 \%)$ in time. Uncertainty of electric supply was expressed by two-third

Table 1: Production constraints faced by the orange grower

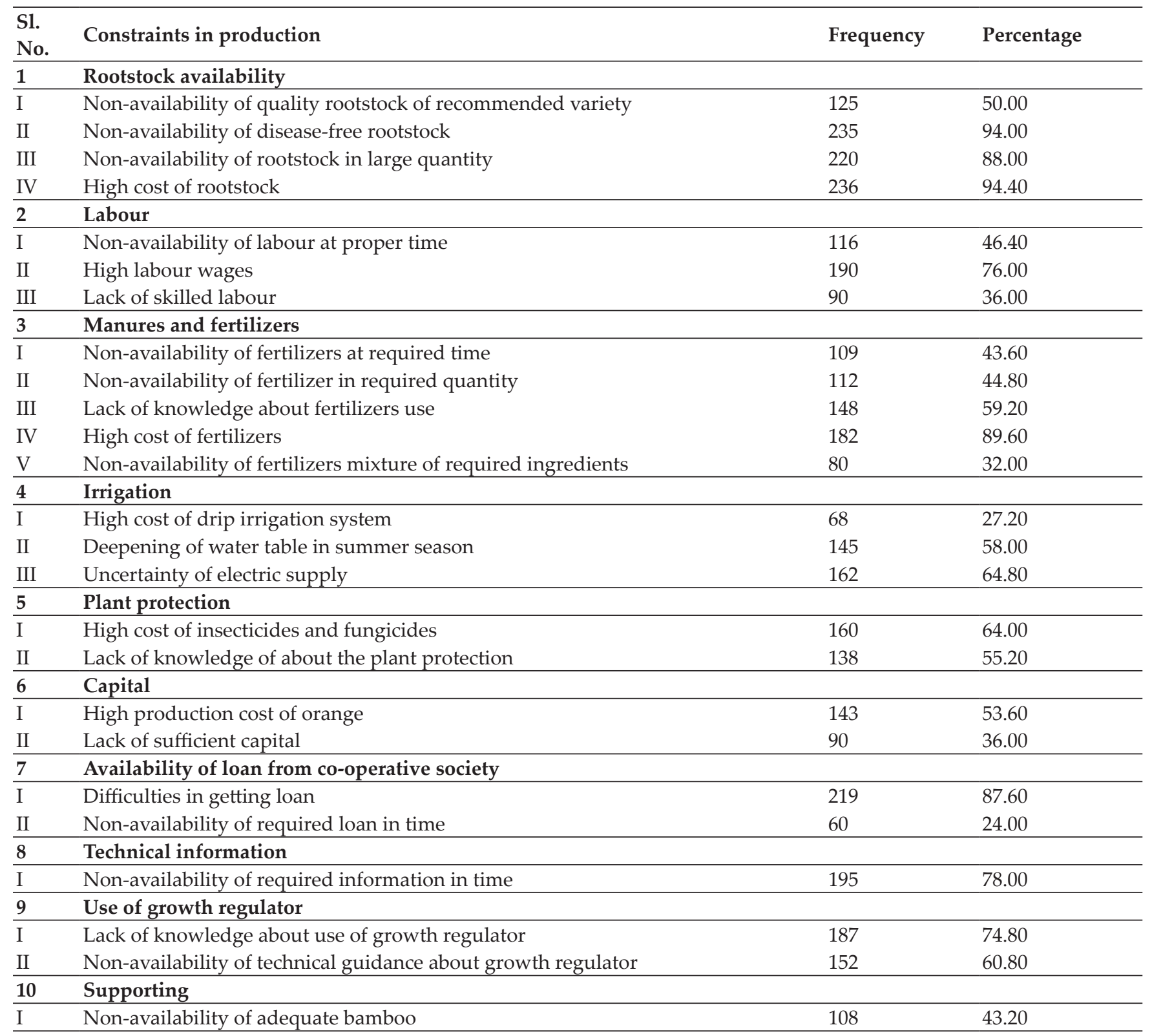


$(64.80 \%)$ of the orange growers and deepening of water level in summer season $(58.00 \%)$ were the major constraints faced by the orange growers. Only 27.20 per cent of the orange growers said that the problem of the high cost of the drip irrigation system in respect of irrigation. Regarding plant protection, major constraints were the high cost of insecticides and fungicides $(64.00 \%)$ and half of the orange growers were lack of knowledge about plant protection $(55.20 \%)$. Major problem to the orange growers about the capital was found that high production cost of orange $(53.60 \%)$ and lack of sufficient capital (36.00\%) (Lakshmi 2000). Other constraints faced by the orange growers regarding the availability of loan from co-operative society were three fourth of the orange growers said that the difficulties in getting the loan $(87.60 \%)$ and a sizeable proportion of the orange growers also indicated that the non-availability of loan of required loan in time $(24.00 \%)$. Non-availability of required information in time was use of the problem regarding technical information expressed by 78.00 per cent of the orange growers. Lack of knowledge $(74.80 \%)$ about the use of growth regulators and non-availability of technical guidance $(60.80 \%)$ with regards to the recommended use of growth regulators. Followed by non-availability of adequate bamboo strick for supporting fruit-bearing trees $(43.20 \%)$ as constraints that restricted the use of recommended cultivation practices for the production of orange fruit. From the above constraints, it is concluded that the important constraints which were encountered by the majority of the orange growers in use of recommended orange production technology were lack of knowledge and technical guidance. About use of growth regulator, high cost of plant protection chemicals, expensive nature of plant protection schedule and non-availability of subsidy in cash and in time for use of fertilizers. Non-availability of disease-free rootstocks, non-availability of rootstock in large quantity and high cost of rootstocks are the constraints faced by the orange growers in the production of orange crop (Meeta 2000).

\section{Marketing constraints faced by the orange growers}

The orange growers were asked to state the difficulties they experienced in marketing orange. A total of ten constraints were identified by the orange growers in the marketing of orange fruits which are depicted in Table 2. The constraints about the marketing system of the orange growers in Table 2 indicated that non-availability of storage facilities in the nearby market and non-establishment of processing units $(100.00 \%)$ was the major constraints regarding the marketing system, followed by the high cost of packing material $(88.00 \%)$, lack of transport facilities $(86.00 \%)$, delayed payments by purchasers or contractors $(68.00 \%)$, fluctuation in prices $(67.60 \%)$, high transportation charges $(66.80 \%)$, low auction price peaded by traders/ contractors due to away of orchard from the main road $(58.00 \%)$ and non-availability of skilled labour for grading $(32.00 \%)$ was the constraints faced by

Table 2: Marketing constraints faced by the orange grower

\begin{tabular}{llll}
\hline Sl. No. & Constraints in marketing & Frequency & Percentage \\
1 & Grading & & \\
I & Non-availability of skilled labour for grading & 80 & 32.00 \\
2 & Transportation & 167 & 66.80 \\
I & High transportation charges & 215 & 86.00 \\
II & Lack of transport facilities & & \\
3 & Sale of produce & 145 & 58.00 \\
I & Low auction price paid by traders/ contractors due to away of orchard from the main & & 68.00 \\
& road & 170 & 100.00 \\
II & Delayed payments by purchasers or contractors & 250 & 67.60 \\
III & Non-establishment of processing units & 169 & 88.00 \\
IV & Fluctuations in prices & & 220 \\
$\mathbf{4}$ & Packaging & & \\
I & High cost of packing material & 250 & 100.00 \\
5 & Storage & & \\
I & Non-availability of storage facilities in a nearby market & &
\end{tabular}


Table 3: Suggestions overcome constraints faced by orange grower about production

\begin{tabular}{llll}
\hline S1. No. & Suggestions & Frequency & Percentage \\
\hline 1 & Availability of fertilizers in time nearest market & 189 & 75.60 \\
2 & Providing subsidy on fertilizer in time & 230 & 92.00 \\
3 & Availability of plant protection chemicals at reasonable cost & 100 & 40.00 \\
4 & Availability of technical guidance about the use of growth regulator & 125 & 50.00 \\
5 & Government should emphasize the development of irrigation facility & 235 & 94.00 \\
6 & Availability of sufficient quantity of bamboo sticks in the nearest market at a & 85 & 34.00 \\
& reasonable price & 65 & 26.00 \\
7 & Organization of skill training for labourers & 149 & 59.60 \\
8 & Availability of adequate literature and technical guidance on cultivation & 210 & 84.00 \\
9 & Assured power supply & 78 & 31.20 \\
10 & Long term credit facilities should be made available & 34 & 13.60 \\
11 & Subsidy on drip irrigation be enhanced & &
\end{tabular}

Table 4: Suggestions overcome constraints faced by orange grower about the marketing of orange

\begin{tabular}{llll}
\hline S1. No. & Suggestions & Frequency & Percentage \\
\hline 1 & Availability of mechanical grading device & 112 & 44.80 \\
2 & Availability of an adequate number of wagons for transportation of orange & 210 & 84.00 \\
3 & Establishment of orange processing units in the orange producing area & 225 & 90.00 \\
4 & Establishment of cold storage facility at reasonable rates & 90 & 36.00 \\
5 & Application of crop insurance scheme for orange growers & 250 & 100.00 \\
6 & Storage facilities should be available in market & 135 & 54.00 \\
7 & Assured minimum price for orange fruits & 230 & 92.00 \\
\hline
\end{tabular}

the orange growers regarding the marketing system of the orange fruits (Jadhav 2003).

\section{Suggestions overcome constraints faced by orange grower about in production of orange}

It could be noted from Table 3 that for overcoming the constraints in the use of orange production technology majority of orange growers suggested that the Government should emphasize the development of irrigation facility $(94.00 \%)$, subsidy on fertilizer $(92.00 \%)$, assured power supply $(84.00 \%)$, fertilizers be made available in time at the nearest market $(75.60 \%)$, adequate literature and technical guidance on orange cultivation should be available $(59.60 \%)$. Half of the orange growers $(50.00 \%)$ also suggested that the availability of the technical guidance from extension functionaries about use of growth regulator, plant protection chemicals available at a reasonable cost $(40.00 \%)$ in the nearest market or at villages or agro service center for overcoming the difficulty and nonavailability of sufficient quantity of bamboo sticks in the nearest market at a reasonable price (34.00\%). A comparative small proportion of orange growers were also pointed out that the long-term credit facilities should be made available (31.20\%) and organization of skill training for labourers (26.00\%) is organized to equip them with the know-how about plant protection and harvesting of orange. Very few of the orange growers expressed that subsidy on drip irrigation is enhanced (13.60\%).

\section{Suggestions of orange growers to overcome the constraints faced in the marketing of orange}

Suggestions for increasing the information behaviour about the marketing of orange growers were secured, their number and percentage were worked out and the suggestions after arrangement have been presented in Table 4 . The suggestions depicted in Table 4 revealed that the majority of the orange growers (100\%) have suggested that to applicable of crop insurance scheme for orange growers followed by minimum price for orange fruits $(92.00 \%)$, availability of an adequate number of wagons for transportation of orange fruits $(84.00 \%)$, half $(54.00 \%)$ of the orange growers suggested that storage facilitates should be available in the market, available mechanical grading device $(44.80 \%)$ and followed by the establishment of the cold storage facility at reasonable rates $(36.00 \%)$. Thus it is essential on the part of the agriculture department to take into consideration the possible 


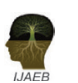

suggestions to increase the information behhaviour about the marketing of the orange growers for desirable outcomes through their information by eliminating the constraints facing them.

\section{CONCLUSION}

This study provided an analysis of the constraints faced by the orange grower in the Amravati District of Maharashtra. Non-availability of rootstock, high cost of rootstock and fertilizers, the uncertainty of electricity supply and difficulties in getting loans were major constraints faced by the farmers which are related to the production. Lack of transport facilities, non-establishment of processing units, and high cost of packing material and non-availability of storage facilities in nearby markets were the major constraints about marketing on orange. Providing subsidy on fertilizer, Government should emphasize the development of irrigation facility, assured power supply were major suggestions about production. Availability of making an adequate number of wagons for transportation of orange, the establishment of orange processing industry in orange producing area, application of crop insurance scheme for orange and assured minimum price for orange produce were major suggestions about marketing.

\section{REFERENCES}

Anonymous, 2002. Technology gap in santra cultivation. Agresco report Department of Extension Education, Dr PDKV, Akola.

Anonymous, 2009. www.agri.maha.nic.in.

Jadhav, 2003. A study of the entrepreneurial behaviour of the Watermelon growers in Raigad district. M.Sc. Thesis (unbub.) Dr. B.S.K.K.V. Dapoli.
Kolhe, R.M. 2000. Communication behaviour of farmers. M.Sc. Thesis (Unpub.), Dr. PDKV, Akola.

Lakshmi, K., Ravikumar, K. N. and Raju, V. T. 2000. Problem of regulated agricultural marketing in Andhra Pradesh. Int. Convention in Agril. Mktg. Management -Challenges in Millennium, held during August 24-25, 2000, MANAGE, Hyderabad (India), pp. 27.

Mahajan, V.R. 2000. Constraints in production, storage and marketing of Banana. M.Sc. Thesis (Unpub.) Dr. PDKV, Akola.

Meeta, K. 2000. Role of vegetable marketing federation (VEGFED) in marketing of vegetables in Bihar. Enclyclopaedia of Agril. Mktg., 4: 123-135.

Mishra, P. and Homa, F. eds., 2019. Essentials of Statistics in Agricultural Sciences. CRC Press.

Mishra, P., Sahu P.K., Padmanaban K., Vishwajith K.P. and Dhekale, B.S. 2015. Study of Instability and Forecasting of Food Grain Production in India. Int. J. Agri. Sci., 7(3): 474-481.

Raju Jagannadha, D. and Jayarama Reddy, K. 2003. Agricultural information management behaviour of farmers. Manage Ext. Res. Review, 4(1): 144-152.

Ramshetwad, B.R. 2001. Adoption of plant protection measures by banana growers. M.Sc. Thesis (Unpub.) Dr. PDKV, Akola.

Sadaphal, P.M. 2000. A study on existing cultivation practices of white onion in Raigad district. M.Sc. Thesis (unpub.) Dr. B.S.K.K.V. Dapoli.

Sunil Kumar, G.M. 2004. A study on farmers knowledge and adoption of production and post-harvest technology in tomato crops of Belgaum district in Karnataka. M.Sc. (Agri.) Thesis, Univ. Agric. Sci., Dharwad (India). 